\title{
Reasonable Responses to Challenges on Strategic Development of Unbalanced Public Service Supply: an Analysis of Governmental Public Service Purchasing Mechanism in China
}

\author{
Fu Lei, Yan Xiong* \\ Yunnan University of Finance and Economics. Kunming. China 650221 \\ (E-mail:f1912284892@163.com, yxiongemail@163.com)
}

\begin{abstract}
With the increasing attention to public service supply in strategic development on a global scale, governments are working on how to provide more efficient and comprehensive public services to tackle challenges of unbalanced public service supply. Seeking a fair governmental purchasing mechanism has become an irresistible trend around the world, and also an urgent issue for central and local governments. It is imminent that how to provide satisfactory public services for the citizen under the circumstances of the market mechanism, while practice of China is a very good reference. To solve unbalanced challenges in the world, this article is trying to discuss Chinese government public services purchasing mechanism, and puts forward the countermeasures and suggestions on improving the government public services purchasing mechanism.
\end{abstract}

Keywords: Public services; Government purchase; Market mechanism

\section{Introduction}

Since the 1970s, there has been rising an innovation movement of the public service with wide range. This wave not only reflected strong dissatisfaction from people of all countries to the public service's poor quality and low efficiency caused by bureaucracy disadvantages, but also reflected determination from governments to complete the comprehensive reform on public service.

In the 1970s, it was the western countries "stagflation" of the macroeconomic situation and the government's crisis of confidence, that became severe challenges to the traditional western effective supply mode of public service. Schultz put forward the new idea to solve the problem: "we always considered by the public sector intervention in the private sector, not in the other way around. Effective reform, sometimes may be the market process of expanding into the nonmarket, or the government sector."

Government purchase of public services is a mechanism of directly providing public service through direct grants or public bidding mode by qualified social service agencies that is employed by the government. Government will choose winning bidder depending on the quality and quantity of public service by the bidder, and then pay the service fee.

\section{The Generation and Development of Government Purchase Public Services Mechanism}

Government purchase of public services, also called partnership for public service supply, can be initially originated from the west in the 19th century, which put forward by British engineers Chadwick.

The reform of public services in Western Europe began in 1979, when Margaret-Thatcher came to power. Western European countries began to explore the reform of public services supply mechanism, and a new face of public service came to present.

It is worth to pay attention that public-private partnership mechanism is particularly prominent. The public-private partnership mechanism is a cooperation that introduces market competition in 
the field of public service by government under the background of a large rise of the monopoly industries. Except in some key areas to maintain public components, there should be private sector to operate business. Taking the German housing and housing rental market as an example. There is an average annual growth rate of $4.7 \%$ of average house prices in Europe from 2000 to 2006, while the German house prices are relatively stable, which are contributed by Germany's long-term housing policy and characteristic of the market structure of integration. The government cooperates with the Housing Cooperative and Housing Association. The government provides around 8\% of affordable housings, and the Housing Association manages about $30 \%$ of the nation's housing rental market. The German housing rental market has been developing stably and sustainably relying on the cooperation between the Housing Association and government in government regulation and the investment at the same time.

\section{The Status Quo of China's Government Purchase of Public Service}

The reform of public service supply mechanism in the 1980s changed the supply mode of public service in the planned economy period. The government purchase public service, which taking supply multiple combination and cooperation as keywords, becomes a new choice and way. Government purchase of public service in mainland China began in Shanghai. In 1995, Social and Cultural Planning Bureau in Pudong New District of Shanghai built recreation center of Luoshan. Shanghai YMCA managed the Luoshan recreation center, entrusted by the state pension services in
1998. Governmental purchase service thus entered practice field in our country for the first time. It comes up clearly in chapter 14 of the 12th five-year plan of national basic public service system that the basic public service system construction promotes the main body in a diversified way, in order to fully give play to the role of market mechanism on the premise of responsibility on government. In addition, on the eighteenth national congress of the communist party of China, it comes up clearly that we must accelerate a government-led, universal, sustainable public service system.

\subsection{The main industry distribution of public service of Chinese government}

The main industry distribution of public service of Chinese government

From the main point of view, Chinese government purchase of public service is mainly concentrated in the following industries:

- Community and management services such as: the old assistance, social assistance, employment introduction, skills training, management of floating population, conflict mediation, and etc.

- Industry and management services such as: the industry survey, statistical analysis, project evaluation, technology, and etc.

- Administration and management services such as: specific social organization consultation, field survey, annual checking pre-qualification, daily management, vocational training, veterans job placement, municipal administration and etc.

\subsection{The way of public service of Chinese government}

On the whole, the way of public service of Chinese government is mainly shown in the stable below: 
Form 1. Basic steps to different ways of purchase

\begin{tabular}{|c|c|c|}
\hline \multicolumn{2}{|l|}{ Ways of purchase } & Basic steps \\
\hline \multicolumn{2}{|l|}{ Contract system } & $\begin{array}{l}\text { The most typical; In order to complete the project, } \\
\text { buyers pay a fee to the service supply partner rely on a } \\
\text { contract signed between buyers and service supply } \\
\text { partner. }\end{array}$ \\
\hline \multicolumn{2}{|c|}{ Direct subsidy system } & \multirow{5}{*}{$\begin{array}{l}\text { Local governments offer certain support to the local } \\
\text { agencies and organizations that undertake public } \\
\text { service by way of funding, physical support, vouchers, } \\
\text { preferential policies and etc. }\end{array}$} \\
\hline Ways of purchase & purpose & \\
\hline Contract system & $\begin{array}{l}\text { Taking advantage of } \\
\text { professional technology } \\
\text { and human resources to } \\
\text { implement effective } \\
\text { public service. }\end{array}$ & \\
\hline $\begin{array}{ll}\text { Direct } & \text { subsidy } \\
\text { system } & \end{array}$ & $\begin{array}{l}\text { Supporting the social } \\
\text { organizations to contract } \\
\text { out public service in case } \\
\text { of supply pressure of } \\
\text { local government. }\end{array}$ & \\
\hline $\begin{array}{l}\text { Project- } \\
\text {-application } \\
\text { system }\end{array}$ & $\begin{array}{l}\text { Targeted, outsourcing, } \\
\text { highly } \quad \text { efficient, } \\
\text { economic public service. }\end{array}$ & \\
\hline \multicolumn{2}{|l|}{$\begin{array}{l}\text { Project- } \\
\text {-application system }\end{array}$} & $\begin{array}{l}\text { Buyers design specific goals of special project for the } \\
\text { social public, and hire subcontractors, who provide } \\
\text { public service. Or according to the requirements, social } \\
\text { organizations apply for an approval to the relevant } \\
\text { government departments. }\end{array}$ \\
\hline
\end{tabular}


Form 2. Case validations to different ways of purchase

\begin{tabular}{|l|l|}
\hline Ways of purchase & Case validation \\
\hline Contract system & $\begin{array}{l}\text { Most tangible assets in the United States Federal } \\
\text { Government are implemented to buy by way of } \\
\text { contract, such as supplies and equipment. }\end{array}$ \\
\hline Direct subsidy system & $\begin{array}{l}\text { Buyers(GW street agency)disburse "star-class- } \\
\text { members" service directly to the most disabled and the } \\
\text { old by the subcontractors(GW street community home } \\
\text { service center) }\end{array}$ \\
\hline Project- & $\begin{array}{l}\text { Buyer (GW street) has implemented project-application } \\
\text { system since 2005.According to the requirements of } \\
\text { citizens, relevant social organizations apply for project } \\
\text { to the GW Street, and then after given examination and } \\
\text { approval from the Project Application Management } \\
\text { Committee, they would get financial support and } \\
\text { operation the project. }\end{array}$ \\
\hline
\end{tabular}

\subsection{The main results of public service of Chinese government}

Chinese government purchase of public service has achieved initial results at present stage, mainly showed below:

- Promoting the change of government function and actualizing the transformation of the government's role. On the one hand, the government has been transforming from all-round government to limited government. On the other hand, the mode of public service has been transforming from a single administrative way into a combination of government, market and social organizations.

- Improving the quality of public service of government departments and constituting the demonstration effect. Public service of government purchase, whose object is society, is close to community, and its characteristics are to provide more diversified and personalized service to public.
Governments need to buy some professional skills and human resources to make up for the original technical defects in some public services. Competition, motivation and rigid constrains of market mechanism, which are the providers of the endogenous innovate power to government and subcontractors, are the reason of excavating the potential on its operation and management, in order to optimize and allocate public service and improve the quality and efficiency of public service significantly.

- Promoting the equitable development between urban and rural, and providing a new way of thinking for the equal basic public service in China. Government purchase of public services is one of the exploratory ways of realizing the equalization of public service between urban and rural by directly providing basic public services to farmers in the vast rural areas. 


\section{The Main Problems ofChina's Government Purchase of Public Service}

There is still some in-adaptation in China from the point of citizens or government, because government purchase of public services belongs to a new thing. Overall, the problems about Chinese government purchase of public services at present are:

4.1 Non-clear buying standards, and fuzzy government responsibility

There is lack of clear standards and specifications on what kind of public service government should buy in the process of government purchase of public services. What's more, the problem is not to ban the participation of private goods buying from government, but how to measure whether the function of government is fully completed under the condition of allowing fiscal capacity.

\subsection{Lower purchase program specification,} bigger cooperation option

There is still lack of unified legal regulations and rules on government purchase of public services to be followed, as Chinese government purchase of public services still in its infancy. The two sides, the buyer and subcontractor, have not determined the reasonable price of public service together in a transparent and fair condition.

4.3. Non-comprehensive evaluation and supervision system, and hard-controlling service cost

There are two aspects on the performance evaluation system of government purchase of public services including the efficiency and the effect evaluation system of purchase of public service. The essence of the former is whether it costs the least to buy the service with a certain amount of funding; and the latter is whether citizens who are the users of public service are satisfied. After the government signing a contact with service producer, it is difficult to have effective evaluation and supervision about contact, especially in condition of lacking of professional services to provide technical regulation.

\subsection{Contributing to the extra cost in the buying} process, but lacking of public trust

Traditionally, Chinese citizens depend on government, and they have accustomed to the management of government. Because of distrusting from citizens on buying public service, there is additional cost in the process of purchasing.

\section{Countermeasures and Suggestions on} Improving the Chinese Government Public Service Purchasing Mechanism

This article tries to put forward suggestions on perfecting our country's government purchase of public services from the structure to the specific measures.

\subsection{Changing ideas and clearing government} position

In order to provide sufficient and highly qualitative public service, we should clear the government role at the new phase. In fact, it is not the transition of responsibility to government purchase of public services. The essence of purchasing of public service is a process assignment of production from government to society and market. But the legitimacy and implementing of public service supply are still the related responsibility to the government.

\subsection{Strengthening system construction, and} building government purchase of public services mechanism

First of all, make sure the scope and standard of government purchase of public services, the definition of serving principle and method, the classification of government purchase of public 
services on the essence of rule level. Secondly, adjust the rules of procedure aspects, such as the procedure, bidding ways, capital verification and management measures, related hearing system of government purchase of public services. Of course, it is also very necessary to maintain a relatively stable supply relationship.

5.3. Establishing strict assessment supervision system, and promoting effective use of public resources

In the process of purchasing of public service, we can try to establish a dynamic way to manage and implement on service project supervision. Dynamic supervision can be conductive to study and make a feedback about the problems in a timely manner. Meanwhile, in the process of evaluation, we should not only focus on the governmental assessment, the evaluation of service's users, but also introduce a third party assessment such as expert's evaluation, citizen evaluation, etc.

\subsection{Improving citizen education, and cultivating well-informed citizens}

The citizen in modern society should have certain knowledge quality, and the consciousness, namely the respect to the law and respect to others, what is the foundation of public service to the government in society. Be aware of that citizen is not only the consumers, but also the participants in public service purchasing. Therefore, we should regard citizens as a constant force of social construction and social improvement. What's more importantly, the improvement of quality of citizens will directly related to the quality of public service supply, so as to avoid the abuse of buying power on public service.

\section{Acknowledgement}

This research was financially supported by my supervisor, Mr.Yan, who had given so much useful advices on writing, and tried his best to improve this article.

\section{References}

(1) Bing, Feng. (2013). Chinese Public Administration Yearbook 2012 [M]. China: Financial Economic Publishing House, 99-121, 374-375

(2) Ferlie, Ewan. (1999). The New Public Management in Action [M].Oxford University Press, New York, 43-45

(3) Hood. (1987). Public Administration, in The Blackwell Encyclopedia of Political Institutions [M].Oxford: Basic Blackwell, 81-90

(4) Puqu, Wang, Salamon, Leicester., M. (2010). The Research of Government to Buy Public Service from Social Organizations: China and global experience[M].Cambridge: University Press, 111121

(5) Schultz, Charles. (1994). Market or Government Weigh the Choice of Two Kinds of Imperfect/Rand Corporation study[M]. Beijing: China press, 146 